\title{
BUILDING FUEL MODELS AND SIMULATING THEIR SURFACE FIRE BEHAVIOR IN THE “SERRA DE ITABAIANA” NATIONAL PARK, SERGIPE, BRAZIL
}

\author{
Benjamin Leonardo Alves White ${ }^{1}$, Adauto Souza Ribeiro², Genésio Tâmara Ribeiro ${ }^{3}$, \\ Rosemeri Melo Souza ${ }^{4}$ \\ ${ }^{1}$ Biologist, M.Sc., Laboratory Geoecology and Territorial Planning, UFS, São Cristovão, SE, Brasil - benjmk@ hotmail.com \\ ${ }^{2}$ Biologist, Dr., Laboratory Biology of Conservation, UFS, São Cristovão, SE, Brasil - adautosr@ufs.br \\ ${ }^{3}$ Forest Engineer, Dr., Laboratory of Entomology, UFS, São Cristovão, SE, Brasil - genesiotr@ hotmail.com \\ ${ }^{4}$ Geographer, Dr., Laboratory Geoecology and Territorial Planning, UFS, São Cristovão, SE, Brasil - rome@ufs.br \\ Recebido para publicação: 10/07/2012 - Aceito para publicação: 16/02/2013
}

\begin{abstract}
The objectives of this research were, for scientific and management purposes, to build fuel models and simulate their fire behavior. Three different vegetation types (shrublands, grass fields and tropical forests) of the "Serra de Itabaiana" National Park were analyzed. The fuel models were developed by destructive sampling and the collected data was inserted in the software "BehavePlus 5.0". The results revealed that the fuel model for the shrublands presented the longest flame length, the highest fireline intensity and the greatest heat release per unit area. The fuel model for the grass fields presented the fastest surface rate of spread; and the fuel model for the tropical forests the lower fire intensity.

Keywords: Fire simulator; BehavePlus; conservation units.
\end{abstract}

\section{Resumo}

Construindo modelos de material combustível e simulando o seu comportamento de fogo no Parque Nacional Serra de Itabaiana, SE. Este estudo foi desenvolvido com o objetivo de construir modelos de material combustível para três diferentes formações vegetacionais (florestas arbustivas, campos graminosos e florestas tropicais), localizadas dentro do Parque Nacional Serra de Itabaiana, e simular o comportamento do fogo dentro dessas fitofisionomias, para efeitos de pesquisa e manejo. Para tal, modelos foram construídos através de amostragem destrutiva e os dados coletados inseridos no programa "BehavePlus 5.0". De acordo com os resultados, o modelo para as florestas arbustivas apresentou o maior comprimento de chamas, a maior intensidade do fogo e a maior quantidade de energia liberada por unidade de área. O modelo para os campos graminosos apresentou maior velocidade de propagação do fogo e, no modelo para as florestas tropicais, o fogo simulado apresentou menor intensidade.

Palavras-chave: Manejo do fogo; BehavePlus; unidades de conservação.

\section{INTRODUCTION}

Forests fires represent one of the biggest threats to reforestation and to native forests of the planet, causing billions of dollars in damage every year. Fire not only affects the survival of all the organisms and modifies the physical and chemical amount of nutrients of the soil, but also pollutes the atmosphere with harmful greenhouse gasses. The majority of conservation lands in Brazil have already suffered heavy ecological losses due to fires, in most cases because of deficient fire management in bordering properties, or as is common in the Amazon, fires resulting from clearing native forest.

The establishment of scenarios based on real values and statistical parameters make possible to calculate average standards of the forest fuel load that, together to values of topography and characterization of weather conditions, allow the prediction of fire behavior (BEUTLING, 2005).

Mathematical models that describe fire behavior began to be developed in the 1940's. The model most accepted, and most used in the literature, is the Richard C. Rothermel's model, developed in 1972 (WELL, 2008). His model is incorporated into many predictive tools used by fire managers today, such as 
BehavePlus (ANDREWS et al., 2002), an update of the original Behave (ANDREWS, 1983). The BehavePlus fire modeling system is a computer program for personal computers. It is based on mathematical models that predict fire behavior (such as flame length and transition to crown fire), fire effects (such as scorch height and tree mortality), and the fire environment (such as fuel moisture and wind adjustment factor) (ANDREWS, 2008).

Fire simulation is flexible and allows the exploration of alternative scenarios with fuel, stand structure, and weather conditions. It can be used for projecting the behavior of a forest fire in progress; for applications of fuel reduction treatments; to estimate fire occurrence danger; for firefighters training; and other fire management operations.

This work aimed to build fuel models for three of the most common vegetations types at the Serra de Itabaiana National Park and simulate their fire behavior using the BehavePlus Fire Modeling System. The simulated results were used to supply information for fire management actions under different scenarios, and generate overall recommendations of how to extinguish the fire. This study was based on the null hypothesis that the characteristics of the fuel and climatic aspect would be similar within the three distinct vegetation types, so the fire characteristics and the combat operations would be the same.

\section{MATERIAL AND METHODS}

\section{Focused area}

The focused site, Serra de Itabaiana National Park, is located in Sergipe, a state in northeast Brazil, at $10^{\circ} 40^{\prime} \mathrm{S}, 37^{\circ} 25^{\prime} \mathrm{W}$ and maximum elevation of $670 \mathrm{~m}$ (Figure 1). The climate, by the Köppen system of classification, is tropical with dry summer (As), with mean annual rainfall of $1200 \mathrm{~mm}$. The grass fields are the most common natural formation (3289 ha), composed by tall dense grass presented mainly in regions of rough relief and hillsides. The principal species found in these areas are: Lagenocarpus rigidus (Cyperaceae), and Xyris brevifolia (Xyridaceae).

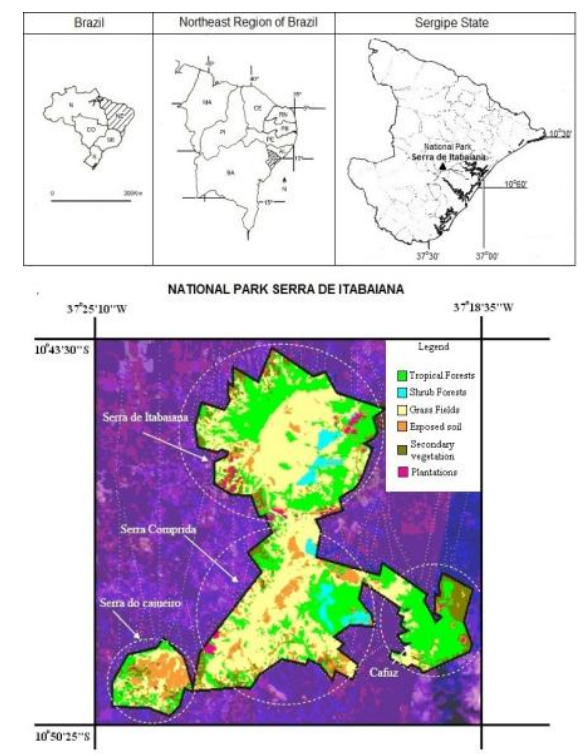

Figure 1. Localization and vegetation types at the Serra de Itabaiana National Park, Sergipe.

Figura 1. Localização e formações vegetacionais encontradas no Parque Nacional Serra de Itabaiana, Sergipe (DANTAS; RIBEIRO, 2010).

On the evergreen lowland tropical forests (2643 ha) the closed and homogeneous canopy can reach 20 meters. These formations are composed by several different species like: Campomanesia viatoris, Stryphnodendron pulcherrimum and Inga laurina. There is no intermediate fuel layer, and the near surface layer is sometimes composed by grasses. The shrublands (347 ha) only occur on the east 
side, composed mainly by shrubs (Ericaceae, Euphorbiaceae, Myrtaceae, Fabaceae and Poligalaceae) sometimes associated with herbaceous vegetation (Aristida setifolia, Andropogon leucostachyus, Melocactus zehntneri and Vellozia dasypus) (DANTAS; RIBEIRO, 2010).

\section{Sampling procedures for building the fuel models}

One hundred and eight plots $(1 \times 1 \mathrm{~m})$ where established inside the three main vegetation types: 36 in areas of tropical forest, 36 in shrublands and 36 in grass fields.

Fuel characterization was done during the fire season months (October through May 2008-2009) and it was utilized destructive sampling techniques with all vegetal biomass until $1.8 \mathrm{~m}$ height (upper limit of the surface fuel complex) collected, separated (accordingly to time lag class) and weighed. In order to standardize the procedure and get a good view of the vegetation under high fire risk conditions, all sampling was done on clear days that hadn't had any rain for the prior 2 days, and between 10 a.m. - 2 p.m when air relative humidity reaches the lowest values and air temperature the highest ones, lowering the fuel moisture (POLLET; BROWN, 2007). Fuel loading was quantified for live fine fuels, live herbaceous fuels, and $1 \mathrm{~h}, 10 \mathrm{~h}$, and $100 \mathrm{~h}$ dead-fuel time lag classes, corresponding to roundwood diameters of < 0.6; $0.6-2.5$ and $2.5-7.6 \mathrm{~cm}$, respectively (BROWN, 1974). The methodologies used to collect, categorize and weigh were based on Rothermel (1972) and Brown et al. (1982).

After fuels were collected, categorized and weighed, a representative sample of each time lag class was removed, placed in a paper bag and weighed. After that, the sample was taken to the laboratory for drying and posterior determination of the fuel moisture content. The drying was done in an oven, at temperature of $\pm 70^{\circ} \mathrm{C}$, for 72 hours. With the 36 samples for each time lag class inside each vegetation, a mean, $70^{\text {th }}$ and $90^{\text {th }}$ extreme percentiles values, was calculated.

The fuel bed depth (distance from the bottom of the litter layer to the highest intersected dead particle) of each vegetation type was measured using the planar intersect technique (BROWN, 1974). An eleven meters line was traced, ant at $30 \mathrm{~cm}$ the fuel bed depth was measured.

The midflame wind speed was obtained at the "Gbarbosa/UFS" Remote Automated Weather Station $\left(10^{\circ} 48^{\prime} \mathrm{S}, 37^{\circ} 24^{\prime} \mathrm{W}\right)$, which is $5 \mathrm{~km}$ northwest from Serra de Itabaiana National Park at the elevation of $173 \mathrm{~m}$. The meteorological station had registered the wind speed each 30 minutes since January 2007. With this data a mean value and high extreme representing the $70^{\text {th }}$ and $90^{\text {th }}$ percentiles were calculated.

The slope steepness was obtained using the Global Mapper 10.0 Geographic Information System (GLOBAL MAPPER LLC, 2009) through "SRTM" slope data maps.

Input values for the surface area to volume ratio, dead fuel moisture of extinction, dead and live fuel heat content were obtained by a literature review, using the Rothermel (1983) comparison methodology, improved by Scott and Burgan (2005).

\section{Describing the fire behavior and generating recommendations for extinguish the fire}

After the fuel models for each vegetation type were built, the data was inserted in the BehavePlus Fire Modeling System 5.0 in order to simulate: maximum surface rate of spread; heat per unit area; fireline intensity; and flame length. Simulations for different weather scenarios and at different slope steepness were conducted as well.

The overall recommendations were based on the characteristics of the fire and on the fire characteristics charts developed to describe forest fire behavior and to supply information for fire management actions at different scenarios (ROTHERMEL, 1983).

\section{RESULTS}

\section{Inputs for each fuel model}

Fuel moisture and fuel load

The highest surface fuel load was from the tropical forests, that presented an average of 12.5 t/ha. The shrublands presented an average of $9.18 \mathrm{t} / \mathrm{ha}$, and the grass fields $3.7 \mathrm{t} / \mathrm{ha}$ (Table 1 ).

Beside the greatest total fuel load, the tropical forest presented the highest mean fuel moisture content. The shrublands presented the least fuel moisture content, except for the live woody class that presented a lesser value in the grass fields (Table 2). 
Table 1. Ovendry surface fuel load of the tropical forests, shrublands and grass fields, at the Serra de Itabaiana National Park, Sergipe, Brazil.

Tabela 1. Cargas do material combustível superficial seco dentro das florestas tropicais, das florestas arbustivas e dos campos graminosos encontradas no Parque Nacional Serra de Itabaiana.

\begin{tabular}{lccc}
\hline Mean fuel load (t/ha) & Grass fields & Tropical forests & Shrublands \\
\hline 1 - h load & $1.36( \pm 0.67)$ & $8.14( \pm 3.22)$ & $5.54( \pm 2.72)$ \\
10 - h load & 0.00 & $1.79( \pm 1.32)$ & $0.66( \pm 0.91)$ \\
100 - h load & 0.00 & $2.01( \pm 3.61)$ & $0.59( \pm 2.05)$ \\
Live herbaceous fuel load & $2.14( \pm 1.38)$ & $0.27( \pm 0.33)$ & $0.41( \pm 0.71)$ \\
Live woody fuel load & $0.21( \pm 0.5)$ & $0.3( \pm 0.38)$ & $1.98( \pm 1.32)$ \\
Total & $3.7( \pm 1.72)$ & $12.5( \pm 6.0)$ & $9.18( \pm 4.58)$ \\
\hline
\end{tabular}

Note: values are the means, \pm standard deviation.

Table 2. Mean fuel moisture content, moisture extreme 70th, and moisture extreme 90th, for grass fields, tropical forests and shrublands at Serra de Itabaiana National Park.

Tabela 2. Valores médios e valores representando $70 \%$ e $90 \%$ extremos do teor de umidade do material combustível, para os campos graminosos, florestas tropicais e florestas arbustivas no Parque Nacional Serra de Itabaiana.

\begin{tabular}{lccc}
\hline Mean fuel moisture content & Grass fields & Tropical forests & Shrublands \\
\hline 1 - h moisture & $18( \pm 8)$ & $32( \pm 20)$ & $14( \pm 8)$ \\
10 - h moisture & - & $26( \pm 17)$ & $11( \pm 7)$ \\
100 - h moisture & - & $34( \pm 21)$ & $6( \pm 3)$ \\
Live herbaceous moisture & $45( \pm 7)$ & $50( \pm 10)$ & $38( \pm 8)$ \\
Live woody moisture & $44( \pm 24)$ & $60( \pm 24)$ & $48( \pm 8)$ \\
\hline Moisture extreme $\mathbf{7 0}^{\text {th }}(\boldsymbol{\%})$ & Grass fields & Tropical forests & Shrublands \\
\hline 1 - h moisture & 12 & 14 & 6 \\
10 - h moisture & - & 13 & 6 \\
100 - h moisture & - & 17 & 33 \\
Live herbaceous moisture & 43 & 46 & 42 \\
Live woody moisture & 36 & 59 & Shrublands \\
\hline Moisture extreme $90^{\text {th }}(\boldsymbol{\%})$ & Grass fields & Tropical forests & 7 \\
\hline 1 - h moisture & 11 & 13 & 5 \\
10 - h moisture & - & 12 & 5 \\
100 - h moisture & - & 11 & 30 \\
Live herbaceous moisture & 36 & 38 & 41 \\
Live woody moisture & 35 & 49 & \\
\hline
\end{tabular}

Fuel bed depth

According the 36 measurements taken within each vegetation type of Serra de Itabaiana National Park, it was determined the average fuel bed depth of the tropical forest as $0.06 \mathrm{~m}$, in the shrublands the average was $0.84 \mathrm{~m}$, and in the grassland $0.44 \mathrm{~m}$. The fuel bed depth is an input value required to determine the fuel bed bulk density $\left(\mathrm{kg} \cdot \mathrm{m}^{-3}\right)$ that is an intermediate value in Rothermel's surface fire spread model. The fuel bed bulk density is the total oven-dried fuel load per cubic volume of fuel bed. These values are presented in table 3 .

Table 3. Fuel bed depth and bulk density for the grass fields, tropical forests and shrublands at Serra de Itabaiana National Park.

Tabela 3. Espessura do leito do material combustível e sua densidade para os campos graminosos, florestas tropicais e florestas arbustivas dentro do Parque Nacional Serra de Itabaiana.

\begin{tabular}{lccc}
\hline & Grass fields & Tropical forests & Shrublands \\
\hline Fuel bed depth $(\mathrm{m})$ & $0.44( \pm 0.2)$ & $0.06( \pm 0.05)$ & $0.84( \pm 0.61)$ \\
Bulk density $\left(\mathrm{kg} . \mathrm{m}^{-3}\right)$ & 0.84 & 20.85 & 1.09 \\
\hline
\end{tabular}


Midflame wind speed

Using 24916 records of the wind speed measured at the Gbarbosa/UFS meteorological station at 30 minutes intervals, during the 2008 and the 2009 fire seasons, a mean value of $8 \mathrm{~km} / \mathrm{h}$ was determined as the $6 \mathrm{~m}$ open terrain wind speed. Fire weather extremes representing the $70^{\text {th }}$ and $90^{\text {th }}$ percentiles had been defined as 11 and $17 \mathrm{~km} / \mathrm{h}$ respectively.

The $6 \mathrm{~m}$ open terrain wind speed was adjusted to midflame height using wind adjustment factors of 0.5 for the grass fields, 0.3 for the shrublands, and 0.15 for the tropical forests (Table 4). The exposition factors were based on Andrews (2008).

Table 4. Midflame wind speed for the grass fields, tropical forests, and the shrublands at Serra de Itabaiana National Park, Sergipe, Brazil.

Tabela 4. Velocidade do vento (1,8 $\mathrm{m}$ de altura) dentro dos campos graminosos, florestas tropicais e florestas arbustivas localizadas no Parque Nacional Serra de Itabaiana.

\begin{tabular}{lcccc}
\hline Vegetation & $\begin{array}{c}\text { Wind } \\
\text { adjustment } \\
\text { factor }\end{array}$ & $\begin{array}{c}\text { Mean midflame wind } \\
\text { speed }(\mathbf{k m} / \mathbf{h})\end{array}$ & $\begin{array}{c}\text { Extreme midflame } \\
\text { wind speed } \\
\mathbf{7 0}^{\text {th }}(\mathbf{k m} / \mathbf{h})\end{array}$ & $\begin{array}{c}\text { Extreme midflame } \\
\text { wind speed } \\
\mathbf{9 0}^{\text {th }}(\mathbf{k m} / \mathbf{h})\end{array}$ \\
\hline Grass fields & 0.5 & 4 & 6 & 8 \\
Tropical forests & 0.15 & 1 & 2 & 3 \\
Shrublands & 0.3 & 2 & 3 & 5 \\
\hline
\end{tabular}

Slope steepness

"SRTM" maps on the Global Mapper 10.0 defined that the terrain slope steepness varies between 0 and 50 degrees in Serra de Itabaiana National Park. In order to observe the effect of the slope on fire simulations, 3 different slope scenarios, were used as input: 0 degrees, 20 degrees and 40 degrees.

Others input variables

The Rothermel (1983) methodology, improved by Scott and Burgan (2005), was used to obtain the surface area per volume ratio and the dead fuel moisture of extinction. This technique is based on the similarity of two vegetations according to the following parameters: fuel load, fuel packing ratio, and the clime. So, the tropical forests were classified into TL9 (very high load broadleaf litter); shrublands into SH8 (high load, humid climate shrub); and grass fields into GR9 (very high load, humid climate grass).

The dead and live fuel heat content was set to $18622 \mathrm{~kJ} / \mathrm{kg}$, value used by Scott and Burgan for all fuel models.

Table 5. Surface area to volume ratio, fuel bed depth, dead fuel moisture of extinction, dead fuel heat content, and live fuel heat content of the GR6, TL9 and SH8 fuel models.

Tabela 5. Área superficial pelo volume, espessura do leito, teor de umidade de extinção do material combustível morto, energia calorífica do material combustível morto e energia calorífica do material combustível vivo para os seguintes modelos: GR6, TL9 e SH8.

\begin{tabular}{lccc}
\hline Fuel model & GR9 & TL9 & SH8 \\
\hline $1-\mathrm{h} \mathrm{SA} / \mathrm{V}\left(\mathrm{m}^{2} / \mathrm{m}^{3}\right)$ & 5906 & 5906 & 2461 \\
Live herbaceous SA $/ \mathrm{V}\left(\mathrm{m}^{2} / \mathrm{m}^{3}\right)$ & 5249 & 5906 & 5906 \\
Live woody SA $/ \mathrm{V}\left(\mathrm{m}^{2} / \mathrm{m}^{3}\right)$ & 4921 & 5249 & 5249 \\
Dead fuel moisture of extinction $(\%)$ & 40 & 35 & 40 \\
Dead fuel heat content $(\mathrm{kJ} / \mathrm{kg})$ & 18622 & 18622 & 18622 \\
Live fuel heat content $(\mathrm{kJ} / \mathrm{kg})$ & 18622 & 18622 & 18622 \\
\hline
\end{tabular}

\section{Simulating the surface fire behavior for each fuel model}

Having in hand all the input variables, the data were inserted in the software "BehavePlus 5.0" where the following outputs were obtained: maximum surface rate of spread; heat per unit area; fireline intensity; and flame length (Tables 6, 7 and 8).

All the simulations were calculated using only the surface fire direction of maximum spread with the head fire going upslope with the wind. 
Table 6. Custom fuel models built for three different vegetation types in Serra de Itabaiana National Park.

Tabela 6. Modelos customizados de material combustível construídos para três distintas fitofisionomias localizadas no Parque Nacional Serra de Itabaiana.

\begin{tabular}{lccc}
\hline Fuel model inputs & Grass fields & Tropical forests & Shrublands \\
\hline Fuel model type & $\mathrm{D}$ & $\mathrm{D}$ & $\mathrm{D}$ \\
1 - $\mathrm{h}$ fuel load $(\mathrm{t} / \mathrm{ha})$ & 1.36 & 8.14 & 5.54 \\
10 - $\mathrm{h}$ fuel load $(\mathrm{t} / \mathrm{ha})$ & 0.00 & 1.79 & 0.66 \\
100 - $\mathrm{h}$ fuel load $(\mathrm{t} / \mathrm{ha})$ & 0.00 & 2.01 & 0.59 \\
Live herbaceous fuel load $(\mathrm{t} / \mathrm{ha})$ & 2.14 & 0.27 & 0.41 \\
Live woody fuel load $(\mathrm{t} / \mathrm{ha})$ & 0.21 & 0.30 & 1.98 \\
1 - h SA $/ \mathrm{V}\left(\mathrm{m}^{2} / \mathrm{m}^{3}\right)$ & 5906 & 5906 & 2461 \\
Live herbaceous SA $/ \mathrm{V}\left(\mathrm{m}^{2} / \mathrm{m}^{3}\right)$ & 5249 & 5906 & 5906 \\
Live woody AS $/ \mathrm{V}\left(\mathrm{m}^{2} / \mathrm{m}^{3}\right)$ & 4921 & 5249 & 5249 \\
Fuel bed depth $(\mathrm{m})$ & 0.44 & 0.06 & 0.84 \\
Dead fuel moisture of extinction $(\%)$ & 40 & 35 & 40 \\
Dead fuel heat content $(\mathrm{kJ} / \mathrm{kg})$ & 18622 & 18622 & 18622 \\
Live fuel heat content $(\mathrm{kJ} / \mathrm{kg})$ & 18622 & 18622 & 18622 \\
\hline
\end{tabular}

Note: All the simulations were done with fuel model type "D" (Dynamic) instead of the fuel model type "S" (Static). Dynamic fuel models have a live herbaceous fuel component, a portion of which is transferred into the dead herbaceous fuel load depending upon the live herbaceous fuel moisture content (the lower the moisture content, the greater the load transfer).

Table 7. Inputs of fuel moisture content and midflame wind speed in the mean, $70^{\text {th }}$ and $90^{\text {th }}$ extreme scenarios.

Tabela 7. Valores de entrada do teor de umidade do material combustível e da velocidade do vento nos cenários médio, $70 \%$ e $90 \%$ extremo.

\begin{tabular}{lccccccccc}
\hline \multirow{2}{*}{ Weather scenarios } & \multicolumn{3}{c}{ Grass fields } & \multicolumn{3}{c}{ Tropical forests } & \multicolumn{3}{c}{ Shrublands } \\
\cline { 2 - 10 } & Mean & $\mathbf{7 0}^{\text {th }}$ & $\mathbf{9 0}^{\text {th }}$ & Mean & $\mathbf{7 0}^{\text {th }}$ & $\mathbf{9 0}^{\text {th }}$ & Mean & $\mathbf{7 0}^{\text {th }}$ & $\mathbf{9 0}^{\text {th }}$ \\
\hline 1 - h moisture (\%) & 18 & 12 & 11 & 32 & 14 & 13 & 14 & 11 & 7 \\
10 - h moisture (\%) & - & - & - & 26 & 13 & 12 & 11 & 6 & 5 \\
100 - h moisture (\%) & - & - & - & 34 & 17 & 11 & 6 & 6 & 5 \\
Live herbaceous moisture (\%) & 45 & 43 & 36 & 50 & 46 & 38 & 38 & 33 & 30 \\
Live woody moisture (\%) & 44 & 36 & 35 & 60 & 59 & 49 & 48 & 42 & 41 \\
$\begin{array}{l}\text { Midflame wind speed } \\
\text { (upslope) }(\mathrm{km} / \mathrm{h})\end{array}$ & 4 & 6 & 8 & 1 & 2 & 3 & 2 & 3 & 5 \\
\hline
\end{tabular}

\section{Describing the fire behavior}

\section{Surface rate of spread}

Based in the simulated results, the grass fields presented the fastest surface fire rate of spread, varying from 6.3 to $40.6 \mathrm{~m} / \mathrm{min}$ depending on slope steepness and weather conditions. In tropical forests the rate of spread was very slow, from 0.0 to $1.3 \mathrm{~m} / \mathrm{min}$. The shrublands rate of speed ranged from 3.6 to $30 \mathrm{~m} / \mathrm{min}$.

According to Rothermel (1972) surface fire spread model incorporated into the BehavePlus, the surface rate of spread is calculated based on the propagating flux ratio, wind coefficient, slope factor, effective heating number, heat of pre-ignition, reaction intensity (which depends on the fuel load and fuel moisture content), and bulk density (which depends on the fuel load and fuel bed depth). Inside tropical forests the fuel load is high, nevertheless it is very compacted, with high moisture content, and lower wind speed (compared to other vegetations) so fires propagate very slowly. For this particular research the moisture content of the fine dead fuels inside the shrublands was lower than the moisture content of this same fuel class in the grass fields, but the rate of spread of grasses was higher than the shrubs, at the same slope steepness, it can also be concluded that the wind speed had a greater influence in rate of spread than the fuel moisture content.

The slope is a positive factor, as all simulations were developed considering that the wind was blowing upslope. In these situations, the wind and slope will tilt the flame over the unburned fuel and bring it to ignition temperature sooner, causing faster spread rates and longer flames. This is why the rate of spread rises when the slope steepness increases. 
Table 8. Outputs obtained by simulations using the BehavePlus 5.0 for three different fuel models at three different weather scenarios and at three slope steepness scenarios.

Tabela 8. Valores de saída obtidos através das simulações realizadas no "BehavePlus 5.0" para três distintos modelos de material combustível em três distintos cenários de climas e três distintos cenários de relevo.

\begin{tabular}{|c|c|c|c|}
\hline Slope degrees & $\mathbf{0}$ & 20 & 40 \\
\hline \multicolumn{4}{|c|}{ Grass fields } \\
\hline Surface rate of spread - mean $(\mathrm{m} / \mathrm{min})$ & 6.3 & 9.2 & 21.8 \\
\hline Surface rate of spread - extreme $70^{\text {th }}(\mathrm{m} / \mathrm{min})$ & 12.9 & 16.5 & 32.0 \\
\hline Surface rate of spread - extreme $90^{\text {th }}(\mathrm{m} / \mathrm{min})$ & 20.2 & 24.1 & 40.6 \\
\hline Heat per unit area - mean $(\mathrm{kJ} / \mathrm{m} 2)$ & 4262 & 4262 & 4262 \\
\hline Heat per unit area - extreme $70^{\text {th }}\left(\mathrm{kJ} / \mathrm{m}^{2}\right)$ & 4503 & 4503 & 4503 \\
\hline Heat per unit area - extreme $90^{\text {th }}\left(\mathrm{kJ} / \mathrm{m}^{2}\right)$ & 4495 & 4495 & 4495 \\
\hline Fireline intensity - mean $(\mathrm{kW} / \mathrm{m})$ & 445 & 653 & 1550 \\
\hline Fireline intensity - extreme $70^{\text {th }}(\mathrm{kW} / \mathrm{m})$ & 969 & 1239 & 2401 \\
\hline Fireline intensity - extreme $90^{\text {th }}(\mathrm{kW} / \mathrm{m})$ & 1515 & 1803 & 3045 \\
\hline Flame length - mean $(\mathrm{m})$ & 1.3 & 1.5 & 2.3 \\
\hline Flame length - extreme $70^{\text {th }}(\mathrm{m})$ & 1.8 & 2.1 & 2.8 \\
\hline Flame length - extreme $90^{\text {th }}(\mathrm{m})$ & 2.2 & 2.4 & 3.1 \\
\hline \multicolumn{4}{|c|}{ Tropical forests } \\
\hline Surface rate of spread - mean $(\mathrm{m} / \mathrm{min})$ & 0.0 & 0.1 & 0.3 \\
\hline Surface rate of spread - extreme $70^{\text {th }}(\mathrm{m} / \mathrm{min})$ & 0.2 & 0.4 & 1.2 \\
\hline Surface rate of spread - extreme $90^{\text {th }}(\mathrm{m} / \mathrm{min})$ & 0.3 & 0.5 & 1.3 \\
\hline Heat per unit area - mean $(\mathrm{kJ} / \mathrm{m} 2)$ & 1836 & 1836 & 1836 \\
\hline Heat per unit area - extreme $70^{\text {th }}\left(\mathrm{kJ} / \mathrm{m}^{2}\right)$ & 4320 & 4320 & 4320 \\
\hline Heat per unit area - extreme $90^{\text {th }}\left(\mathrm{kJ} / \mathrm{m}^{2}\right)$ & 4360 & 4360 & 4360 \\
\hline Fireline intensity - mean $(\mathrm{kW} / \mathrm{m})$ & 1 & 3 & 10 \\
\hline Fireline intensity - extreme $70^{\text {th }}(\mathrm{kW} / \mathrm{m})$ & 14 & 28 & 86 \\
\hline Fireline intensity - extreme $90^{\text {th }}(\mathrm{kW} / \mathrm{m})$ & 21 & 35 & 96 \\
\hline Flame length - mean $(m)$ & 0.1 & 0.1 & 0.2 \\
\hline Flame length - extreme $70^{\text {th }}(\mathrm{m})$ & 0.3 & 0.4 & 0.6 \\
\hline Flame length - extreme $90^{\text {th }}(\mathrm{m})$ & 0.3 & 0.4 & 0.6 \\
\hline \multicolumn{4}{|c|}{ Shrublands } \\
\hline Surface rate of spread - mean $(\mathrm{m} / \mathrm{min})$ & 3.6 & 6.1 & 17.1 \\
\hline Surface rate of spread - extreme $70^{\text {th }}(\mathrm{m} / \mathrm{min})$ & 6.1 & 9.0 & 21.6 \\
\hline Surface rate of spread - extreme $90^{\text {th }}(\mathrm{m} / \mathrm{min})$ & 12.1 & 15.5 & 30.0 \\
\hline Heat per unit area - mean $\left(\mathrm{kJ} / \mathrm{m}^{2}\right)$ & 9979 & 9979 & 9979 \\
\hline Heat per unit area - extreme $70^{\text {th }}\left(\mathrm{kJ} / \mathrm{m}^{2}\right)$ & 10403 & 10403 & 10403 \\
\hline Heat per unit area - extreme $90^{\text {th }}\left(\mathrm{kJ} / \mathrm{m}^{2}\right)$ & 11319 & 11319 & 11319 \\
\hline Fireline intensity - mean $(\mathrm{kW} / \mathrm{m})$ & 597 & 1020 & 2847 \\
\hline Fireline intensity - extreme $70^{\text {th }}(\mathrm{kW} / \mathrm{m})$ & 1063 & 1567 & 3739 \\
\hline Fireline intensity - extreme $90^{\text {th }}(\mathrm{kW} / \mathrm{m})$ & 2292 & 2927 & 5666 \\
\hline Flame length - mean $(m)$ & 1.5 & 1.9 & 3.0 \\
\hline Flame length - extreme $70^{\text {th }}(\mathrm{m})$ & 1.9 & 2.3 & 3.4 \\
\hline Flame length - extreme $90^{\text {th }}(\mathrm{m})$ & 2.7 & 3.0 & 4.1 \\
\hline
\end{tabular}

Rate of spread is a fire characteristic that is commonly used by fire managers and fire risk systems to define the principal ways to fight it. Fernandes (2009), analyzing the rate of speed of experimental burns in a maritime pine stand in Portugal, built a new model and used as independent variables: wind speed, moisture content of fine dead fuels, and slope steepness. These were, in decreasing order, the most influential variables that affected the fire spread rate. Experimental fires used to validate such model had rates of spread from $0.36-7.2 \mathrm{~m} \cdot \mathrm{min}^{-1}$.

A new fire spread model for dry eucalypt forest in Australia was developed by Gould et al. (2007). According to such model, the rate of spread is defined by the wind speed, moisture content of the 
dead fine fuel $(1 \mathrm{~h})$, and the surface and near surface hazard score (score defined according to proportion of dead material, fuel load, and litter depth). Experimental fires used to validate such model had rates of spread $2.5-16 \mathrm{~m} \cdot \mathrm{min}^{-1}$.

Fireline intensity

As well as in surface rate of spread, there is a high discrepancy between the fireline intensity in tropical forests and other vegetations; it can be clearly observed effect of slope and weather on their values. According to Byram (1959) equation for the fireline intensity incorporated into the BehavePlus, the intensity will vary depending upon three variables: rate of spread, available fuel, and heat content. As these three variables increase, as the fireline intensity rises. Therefore, the higher the slope steepness and rate of spread, consequently, the higher the fireline intensity.

For the same slope steepness, the grass fields have a higher rate of spread, however in the shrublands there is much more fuel available and by this reason the fireline intensity is greater.

\section{Heat per unit area}

Heat per unit area is the heat energy released per area within the flaming front of the surface fuel and it is not affected by wind and slope (ROTHERMEL, 1972; ANDREWS, 2008). The amount of heat released is a variable that characterizes the fire severity, and the more heat energy that is released, the higher is tree mortality and risk to the fire fighters.

According to Rothermel (1972) equations incorporated into the BehavePlus, the heat per unit area is defined by dividing the fireline intensity by the rate of spread. Since the shrublands have the highest fireline intensity and a slower rate of spread, as compared to grass fields, it obviously will have a higher heat per unit area. The tropical forests and the grass fields at the $70^{\text {th }}$ and $90^{\text {th }}$ extreme scenarios presented almost the same value. The fast rate of spread in the grass fields in these scenarios is the reason they have almost the same heat per unit area as the tropical forests.

\section{Flame length}

Flame length is an important measure of the heat of a fire and hence its severity, both in terms of suppression difficulty and impact on biota (BYRAM, 1959). According to the Byram (1959) equation incorporated into the BehavePlus, flame length will depend only on the fireline intensity. So the higher the fireline intensity, the higher the flame length. The results reveal that in tropical forests the flame length is very short (up to $0.6 \mathrm{~m}$ ) compared to other vegetations. The longest flame length was simulated in the shrublands (up to $4.1 \mathrm{~m}$ ).

Fernandes (2009), analyzing the flame length in a maritime pine located in Sevivas, Portugal, concluded that the two variables that were correlated to the flame length of the experimental burns in decreasing order were: rate of spread, and moisture content of fine dead surface fuels. The author developed a model to forecast the flame length in the focused area using these variables. His model presented better results than the Byram model $\left(r^{2}=0.81\right)$. Experimental fires used to validate the model had flame length from 0.5 to $4 \mathrm{~m}$.

The Project Vesta model (GOULD et al., 2007) correlate the flame height with the fire rate of spread and the elevated fuel height $\left(r^{2}=0.81\right)$. Their flame height model predicts reasonably well when flame heights of surface fire are lower than $8 \mathrm{~m}$, but predicts insufficient flame height when there is torching or crown fires in Australia dry eucalypt forests.

\section{Overall recommendations}

In the tropical forests the fires can always be attacked at the head or flanks by using hand tools. The hand line should hold the fire even at high slope steepness and in extreme weather conditions. Considering that this type of vegetation had the highest fuel moisture content, the probability of an ignition source that initiates a forest fire is unlikely. The slow rate of spread facilitates combative actions.

The fires in the shrublands and in the grass fields at 0 and 20 slope degrees in the mean and $70^{\text {th }}$ extreme scenarios are too intense for direct attack on the head by using hand tolls, and a hand line cannot be relied on to hold the fire. In these scenarios equipment such as dozers, pumpers and aircraft that spray fire retardant can be effective. 
Control efforts at the fire head will probably be ineffective and may present serious control problems, such as torching out, crowning and spotting in the following scenarios: shrublands at 0 and 20 degrees in the $90^{\text {th }}$ extreme scenario; shrublands at 40 degrees in the mean scenario; grass fields at 0 and 20 degrees in the $90^{\text {th }}$ extreme scenario; and grass fields at 40 degrees in the mean and $70^{\text {th }}$ extreme scenarios.

The worse cases were simulated at 40 degrees in the $70^{\text {th }}$ and $90^{\text {th }}$ extreme scenarios for the shrublands and in the $90^{\text {th }}$ extreme for the grass fields formations. In these cases control efforts at the head of fire are ineffective. Crowning, spotting, and major fires runs are probable.

The greatest difficulty in forest fire suppression effort in grass fields is the high propagation speed that can reach $57.8 \mathrm{~m} / \mathrm{min}$ or $3.47 \mathrm{~km} / \mathrm{h}$. Therefore it is necessary that the firefighting crews have high mobility in off-road transports.

In the shrublands the greatest difficulty to combat the fire is the high heat per unit area, fireline intensity, and flame length. The large amount of heat released during the fire make impossible the proximity of the fighting forces so, it is necessary in all scenarios, big equipment use to combat the fire in this vegetation.

\section{DISCUSSION}

Because difficulties involved in the process of obtaining the BehavePlus input variables, and the fact that it is a new software (first version created in 2002), there are not many published works using this tool. The majority of the studies were carried out in the United States, Portugal, and other regions of eastern Europe. Even though it is common to find studies that quantify the fuel load for different Brazilian vegetation types, especially for Cerrado, pine and eucalyptus forests (eg. CASTRO; KAUFFMAN, 1998; RIBEIRO; SOARES, 1998; MIRANDA et al., 2002; SOUZA et al., 2003; SOUZA et al. 2003(b)), this is the only work that the authors know of, that has built custom fuel models for Brazilian vegetation types and uses them in the BehavePlus to simulate forest fire behavior.

BehavePlus system has many applications. Vollmer (2005) and Mohr et al. (2004), for example, use to verify the efficiency of fuel reduction treatments, such as prescribed burning, mechanical and chemical treatment; Hood et al. (2007) used the module "Mortality" to determine the after-fire mortality of 13 species of coniferous trees in the states of Arizona, California, Idaho, Montana and Wyoming; Curt and Delcros (2007) used the module "Ignite" and "Surface" to simulate the fire ignition and initial propagation in road-forest interfaces, focusing on byways and state ways around Aix-en-Provence (southern France); and Dimitrakopoulos (2002) used to delineate the potential fire behavior from Mediterranean fuel models in Greece. With the inputs properly inserted into the BehavePlus all these applications can be done for any vegetation type anywhere in the world, however, the use of this software or even efficient strategies in order to extinguish a forest fire in progress inside Brazilian conservation lands is not common. What usually happens is that the firefighters and the people who live nearby are called to put out the fire without any strategy, just attacking directly the fire front.

Better understanding of the nature of a fire under different scenarios and delineating strategies and orientations for the combat forces using mathematical models that simulate fire behavior is a powerful tool that fire managers should use to diminish damage to ecosystems.

Researches improved in natural forest fuels are relatively scarce, but satisfactory results are common in diverse types of vegetation, especially in brush and herbaceous formations (FERNANDES, 2002). Nevertheless, there are some studies that concluded that the BehavePlus usually underestimates the data obtained from experimental burnings (STREEKS et al., 2005; STEPHENS et al., 2008, FERNANDES, 2009). Therefore, it is recommended that the BehavePlus should be used only by experienced forest fire managers who can combine the simulated results with field experience, to forecast the fire behavior with superior effectiveness. It is essential that the fire manager knows that the software is an auxiliary tool and the decisions must not be taken based solely on its simulations.

Some authors consider that the "Behave" system has more efficient results especially when the values of the characteristics of the fuel are measured and used directly (methodology adopted in this work), instead of using some standard fuel model (GRABNER et al., 1997; BROSE, 1997). However some errors may still occur when the diversity of the fuel is not considered, assuming that conditions are constant. So, it is important to give special attention to fuel characterization methodology and compare the simulated data with real forest fire behavior. This way the program can be used without any restriction for the focused area. 


\section{CONCLUSION}

Due to differences in fuel and wind aspects, simulated fires revealed a peculiar behavior within each developed fuel model. The fuel model for the shrublands had the longest flame length, the highest fireline intensity and the greatest heat per unit area. The fuel model for the grass fields presented the fastest surface rate of spread and the fuel model for the tropical forests presented simulated fires with lesser intensity for all analyzed outputs.

\section{ACKNOWLEDGMENT}

For the Deutscher Akademischer Austauschdienst (DAAD) scholarship fund awarded to the first author.

\section{REFERENCES}

ANDREWS, P. L. A system for predicting the behaviour of forest and range fires. In: CARROLL, J. M. (ed.). Computer simulation in emergency planning. California, U.S. Society for Computer Simulation. Simulatiom Councils, 1983. p. 75 - 85.

ANDREWS, P. L. BEHAVEPlus fire modeling system, version 4.0: Variables. United States Department of Agriculture. Forest Service. General Technical Report RMRS-GTR-213WWW. Fort Collins, CO, 2008.

ANDREWS, P. L.; BEVINS, C.; CARLTON, D. BEHAVEPlus fire modeling system. Version 1.0: user's guide. United States Department of Agriculture, Forest Service, Rocky Mountain Research Station, Systems for Environmental Management. Fort Collins, CO, 2002.

BEUTLING, A. Caracterização para modelagem de material combustível superficial em reflorestamento de Araucaria angustifolia (Bert.) O. Ktze. Curitiba, 2005. Dissertação (Mestrado em Ciências Florestais), Setor de Ciências Agrárias, Universidade Federal do Paraná.

BROSE, P. H. Effects of seasonal prescribed fires on oak-dominated shelterwood stands. Clemson University. South Carolina, 1997.

BROWN, J. K. Handbook for inventorying downed woody material. United States Department of Agriculture, Forest Service. Gen. Tech. Rep. INT-16. Ogden, UT, 1974.

BROWN, J. K.; OBERHEU, R. D.; JOHNSTON, C. M. Handbook for inventorying surface fuels and biomass in the interior west. United States Department of Agriculture, Forest Service. Gen. Tech. Rep. INT-129. Ogden, UT, 1982.

BYRAM, G. M. Combustion of forest fuels. In: DAVIS, K. P. (ed.) Forest Fire Control and Use. McGraw-Hill Book Company, New York, 1959. p. 61 - 89.

CASTRO, E. A.; KAUFFMAN, J. B. Ecosystem structure in the Brazilian Cerrado: a vegetation gradient of aboveground biomass, root mass and consumption by fire. Journal of Tropical Ecology, v. 14, p. 263 - 283, 1998.

CURT, T.; DELCROS, P. Simulating fire ignition and initial propagation at road-forest interfaces. In: 4th International Wildland Fire Conference. Thematic session n ${ }^{\circ}$ 2. Sevilha, Espanha, 2007.

DANTAS, T. V. P.; RIBEIRO, A. S. Caracterização da vegetação do Parque Nacional Serra de Itabaiana, Sergipe, Brasil. Biotemas, v. 23, p. 9 - 18, 2010.

DIMITRAKOPOULOS A. P. Mediterranean fuel models and potential fire behaviour in Greece. International Journal of Wildland Fire, v. 11, p. 127 - 130, 2002.

FERNANDES, P. A. M. Desenvolvimento de relações preditivas para uso no planeamento de fogo controlado em povoamentos de Pinus pinaster Ait. 268 f. Tese (Doutorado em Ciências Agrárias Ciências Florestais) - Universidade de Trás-os-Montes e Alto Douro, Vila Real, 2002.

Examining fuel treatment longevity through experimental and simulated surface fire behaviour: a maritime pine case study. Canadian Journal of Forest Research, v. 39, p. 2529 - 2535, 2009.

GLOBAL MAPPER LLC. Global Mapper Software LLC. Parker, CO, 2009. 
GOULD, J. S.; MCCAW, W. L.; CHENEY, N. P.; ELLIS, P. F.; KNIGHT, I. K.; SULLIVAN, A. L. Project Vesta-Fire in Dry Eucalypt Forest: Fuel Structure, Fuel Dynamics and Fire Behaviour. EnsisCSIRO, Canberra ACT, and Department of Environment and Conservation. Perth, WA, 2007, 218 p.

GRABNER, K.; DWYER, J.; CUTTER, B. Validation of Behave Fire Behavior Predictions in Oak Savannas using five fuel models. In: PALLARDY, S. G.; CECICH, R. A.; GARRETT, E. H.; JOHNSON, P. S. (eds.) 11TH CENTRAL HARDWOOD FOREST CONFERENCE. Proceedings... US Department of Agriculture, Forest Service, General Technical Report NC-188. Columbia, MO, 1997, p. $202-215$.

HOOD, S. M.; MCHUGH, C. W.; RYAN, K. C.; REINHARDT, E.; SMITH, S. L. Evaluation of a postfire tree mortality model for western USA conifers. International Journal of Wildland Fire, v. 16, p. 679 - 689, 2007.

MIRANDA, H. S.; BUSTAMANTE, M. M. C.; MIRANDA, A. C. The Fire Factor. In: OLIVEIRA, P. S.; MARQUIS R. J. (eds.). The Cerrados of Brazil: Ecology and Natural History of a Neotropical Savanna. Columbia University Press, Chichester, West Sussex, 2002.

MOHR, H. H.; WALDROP, T. A.; RIDEOUT, S.; PHILLIPS, R. J.; FLINT, C. T. Effectiveness of fire and fire surrogate treatments for controlling wildfire behavior in Piedmont Forests: a simulation study. In: CONNOR, K. F. (ed) 12TH BIENNIAL SOUTHERN SILVICULTURAL RESEARCH CONFERENCE. Proceedings... Department of Agriculture, Forest Service, Southern Research Station, Gen. Tech. Rep. SRS-71. Asheville, NC, 2004. p. 71 - 73.

POLLET, J.; BROWN, A. Fuel Moisture Sampling Guide. Bureau of Land Management, Utah State Office, Salt Lake City, Utah, 2007. 30 p.

RIBEIRO, G. A.; SOARES, R. V. Caracterização do material combustível superficial e efeitos da queima controlada sobre sua redução em um povoamento de Eucalyptus viminalis. CERNE, Lavras, v. 4, n. 1, p. 57 - 72, 1998.

ROTHERMEL, R. C. A mathematical model for predicting fire spread in wildland fuels. United States Department of Agriculture, Forest Service, Intermountain Forest and Range Experiment Station, Research Paper INT-115. Ogden, UT, 1972.

How to Predict the Spread and Intensity of Forest and Range Fires. United States Department of Agriculture, Forest Service, Intermountain and Range Experiment Station. General Technical Report INT-143. Ogden, UT, 1983. $166 \mathrm{p}$.

SCOTT, J. H.; BURGAN, R. E. Standard fire behavior fuel models: a comprehensive set for use with Rothermel's surface fire spread model. United States Department of Agriculture, Forest Service, Rocky Mountain Research Station. Gen. Tech. Rep. RMRS-GTR-153. Fort Collins, CO, 2005.

SOUZA, L. J. B.; SOARES, R. V.; BATISTA, A. C. Modelagem do material combustível superficial em povoamentos de Eucalyptus dunnii, em Três Barras, SC. CERNE, Lavras, v. 9, n. 2, p. 231 - 245, 2003.

Modelagem de material combustível em plantações de Pinus taeda no norte de Santa Catarina. Floresta, v. 33, n. 2, p. 157 - 168, 2003(b).

STEPHENS, S. L.; WEISE, D. R.; FRY, D. L.; KEIFFER, R. J.; DAWSON, J.; KOO, E.; POTTS, J.; PAGNI, P. J. Measuring the Rate of Spread of Chaparral Prescribed Fires in Northern California. Fire Ecology, v. 4, p. 74 - 86, 2008.

STREEKS, T. J.; OWENS, M. K.; WHISENANT, S. G. Examining fire behavior in mesquite-acacia shrublands. International Journal of Wildland Fire, v. 14, p. 131 - 140, 2005.

VOLLMER, J. L. New Technology for Fuel Breaks and Green Strips in Urban Interface and Wildland Areas. In: BUTLER, B. W.; ALEXANDER, M. E. (eds.) 8TH INTERNATIONAL WILDLAND FIREFIGHTER SAFETY SUMMIT - HUMAN FACTORS - 10 YEARS LATER. Proceedings... The International Association of Wildland Fire, Missoula, MT, 2005.

WELLS, G. The Rothermel Fire-Spread Model: Still Running Like a Champ. Fire Science Digest, v. 2, p. $1-12,2008$. 
